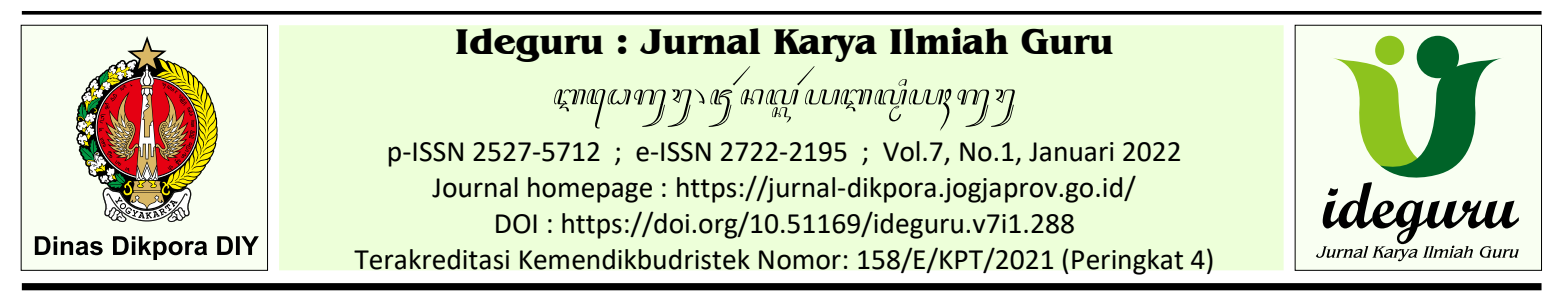

Artikel Penelitian - Naskah dikirim: 17/05/2021 - Selesai revisi: 21/10/2021 - Disetujui: 22/10/2021 - Diterbitkan: 01/01/2022

\title{
Model Pembelajaran Kooperatif "Dapil Tebu Itam" untuk Meningkatkan Kemampuan Menulis Naskah Drama
}

\author{
Handri Purwaningtyas \\ SMA Negeri 1 Banguntapan, Bantul, Daerah Istimewa Yogyakarta, Indonesia \\ handri0503@gmail.com
}

\begin{abstract}
Abstrak: Penelitian ini bertujuan untuk mengetahui peningkatan kemampuan menulis naskah drama siswa kelas XI SMAN 1 Banguntapan dengan menggunakan model pembelajaran Kooperatif "Dapil Tebu Itam". Metode penelitian yang digunakan adalah penelitian tindakan kelas atau classroom action research. Penelitian dilaksana kandalam dua siklus, tiap siklus dilaksanakan dua kali tatap muka. Semua siklus menerapkan model pembelajaran Kooperatif "Dapil Tebu Itam" dengan berbagai variasi kegiatan. Subjek penelitiannya adalah siswa kelas XI IPS 1 SMA Negeri 1 Banguntapan, sedangkan objeknya adalah kemampuan menulisnaskah drama. Data dan instrument dalam penelitian ini adalah instrumen penilaian kemampuan menulis naskah drama siswa dan instrumen observasi keaktifan siswa. Teknik analisis data dalam penelitian ini menggunakan analisis deskriptif kualitatif. Berdasarkan hasil penelitian dapat diambil kesimpulan bahwa dengan menerapkan model pembelajaran Kooperatif "Dapil Tebu Itam" kemampuan siswa dalam menulis naskah drama meningkat. Hal ini dibuktikan oleh data sebagai berikut: (1) Sebelum diberikan tindakan hasil nilai rerata kelas menunjukkan hasil yang rendah, yaitu hanya 50\% siswa yang nilainya mencapai KKM 76.00, sedangkan 50\% lainnya di bawah KKM; (2) Setelah dilakukan tindakan pada siklus pertama nilai rerata kelas meningkat, siswa yang berhasil mencapai KKM sebanyak 62,5\%, sedangkan siswa yang nilainya belum KKM 37\%. (3) Pada siklus kedua, nilai siswa yang sudah mencapai KKM meningkat menjadi $100 \%$.
\end{abstract}

Kata kunci: menulis; naskah drama; model kooperatif; dapil tebu itam.

\section{Cooperative Learning Model "Dapil Tebu Itam" to Improve the Ability of Writing Drama Scripts}

\begin{abstract}
This study aims to determine the improvement of the ability to write drama scripts for class XI students of SMAN 1 Banguntapan by using the cooperative learning model "Dapil Tebu Itam". The research method used is classroom action research. It is carried out in two cycles, each cycle has two meetings. All cycles apply the Cooperative learning model "Dapil TebuItam" with a variety of activities. The research subjects are students of class XI IPS 1 SMA Negeri 1 Banguntapan, while the object is the ability to write drama scripts. The data and instruments in this study were the instrument for assessing students' drama script writing skills and an instrument for observing student activity. The data analysis technique in this study used descriptive qualitative analysis. Based on the results of the study, it can be concluded that by applying the cooperative learning model "Dapil Tebu Itam" students' ability to write drama scripts increases. This is evidenced by the following data: (1) Before the action was given, the class average scores showed low results, namely only 50\% of students whose scores reached the KKM 76.00, while the other $50 \%$ were below the KKM; (2) After taking action in the first cycle, the average value of the class increased, students who managed to reach the KKM were 62.5\%, while students whose grades had not KKM were $37 \%$. (3) In the second cycle, the score of students who have reached the KKM increases to $100 \%$.
\end{abstract}

Keywords: writing; drama script; cooperative model; dapil tebu itam.

\section{Pendahuluan}

Salah satu upaya meningkatkan kualitas Sumber Daya Manusia (SDM) adalah melalui pendidikan di sekolah. Maka dari itu proses pembelajarannya harus selalu mengikuti perkembangan dan kebutuhan zaman. Undang-
Undang Republik Indonesia Nomor 20 Tahun 2003 mengisyaratkan bahwa proses pembelajaran harus direformasi. Untuk itulah ditetapkan adanya standar proses, seperti tertuang dalam Permendiknas Nomor 41 Tahun 2007. 
Depdiknas (2006: 1) menegaskan, pembelajaran Bahasa Indonesia ditujukan untuk meningkatkan keterampilan berkomunikasi siswa dalam berbahasa Indonesia, baik keterampilan berbicara maupun keterampilan menulis secara baik dan benar. Siswa juga diharapkan dapat mengapresiasi karya sastra.

Kemampuan berapresiasi berpikir, berekspresi, berkreasi, dan berimajinasi yang tumbuh melalui kegiatan bersastraakan sangat memengaruhi keterampilan siswa dalam berekspresi, menyampaikan ide, menyampaikan pemikiran dan perasaan, serta keberanian berpendapat melaluibahasa. Kegiatanbersastra juga mampu menimbulkan rasa percaya diri siswa. Berbagai keterampilan itu akan lebih efektif dan lebih mengena jika dipupuk melalui kegiatan menciptakan sebuah karya sastra (Tarigan,1993: 21).

Mengacu pada silabus Mata Pelajaran Bahasa Indonesia SMA Kurikulum 2013, salah satu materi pembelajaran Bahasa Indonesia kelas XI SMA adalah menulis naskah drama. Kenyataa membuktikan bahwa kemampuan bersastra siswa kelas XI IPS 1 SMA 1 Banguntapan masih rendah, terkhusus kemampuan menulis naskah drama. Data yang dapat dijadikan bukti adalah nilai rata-rata kelas 70,00 di bawah KKM 76,00. Rendahnya kemampuan menulis naskah drama disebabkan adanya kendala secara internal dan eksternal. Rendahnya motivasi belajar, rendahnya kemampuan kognitif, juga sikap yang kurang positif terhadap proses pembelajaran, merupakan kendala internal. Akibatnya, siswa bermalas- malasan ketika mengikuti proses pembelajaran dan terkesan menyepelekan. Sehingga tugas menulis naskah drama diubah oleh mereka menjadi meng-copy paste naskah drama yang ada di internet. Termasuk kendala eksternal yaitu lingkungan belajar siswa yang kurang mendukung, pendekatan, strategi, metode, media, pengelolaan kelas, evaluasi, sumber dan sarana pembelajaran, serta model pembelajaran yang konvensional dan monoton. Itu semua juga mempunyai andil yang lumayan besar terhadap rendahnya nilai kemampuan menulis naskah drama pada siswa.

Dari kendala di atas, masalah yang paling pokok yang dihadapi siswa kelas XI IPS 1 SMAN 1 Banguntapan adalah: Siswa kesulitan memunculkan dan menuangkan ide kedala mbentuk naskah drama, siswa kesulitan mengembangkan unsur cerita yakni: tema, alur, latar, tokoh/penokohan, dan amanat. Oleh karena itulah peneliti berupaya merancang pembelajaran dengan menerapkan sebuah model pembelajaran dengan harapan kemampuan menulis naskah drama pada siswa kelas XI IPS1 menjadi lebih baik.

Berdasarkan latar belakang di atas maka penulis menetapkan judul penelitian Model Pembelajaran Kooperatif "Dapil Tebu Itam" untuk Meningkatkan Kemampuan Menulis Naskah Drama.

Rumusan masalah dalam penelitian ini adalah bagaimana menerapkan model pembelajaran Kooperatif Dapil Tebu Itam untuk meningkatkan kemampuan menulis naskah drama siswa Kelas XI IPS1 SMA Negeri 1 Banguntapan?

Tujuan penelitian ini adalah mengetahui peningkatan kemampuan menulis naskah drama siswa Kelas XI IPS1 SMA Negeri 1 Banguntapan melalui penerapan model pembelajaran Kooperatif Dapil Tebu Itam.

Dari empat keterampilan berbahasa yaitu menyimak, berbicara, membaca, dan menulis, menulis merupakan keterampilan berbahasa yang sering dianggap sebagai keterampilan yang lebih kompleks. Penulis harus dapat menuangkan ide dan menyusunnya secara terstruktur. Oleh sebab itu dalam kegiatan menulis ada dua hal yang dijadikan perhatian, yaitu menulis sebagai proses dan menulis untuk menghasilkan sebuah karya dalam bentuk tulisan.

Kemampuan menulis adalah kemampuan menyampaikan ide pemikiran kepadaorang lain secara tertulis. Agar gagasan yang disampaikan dapat dipahami maka penulis harus memiliki kemampuan menggunakan bahasa dengan tepat, penguasaan kosa kata yang tepat, dan memiliki pemahaman terhadap kaidah tata bahasa dan ejaan yang benar. Penulis juga harus memerhatikan konteksnya. (Tim Peneliti Pascasarjana, 2001: 7).

Tarigan, (1993: 21) mengatakan, menulis ialah menurunkan atau melukiskan lambanglambang grafik dari suatu bahasa yang dapat dibaca dan dipahami, serta memiliki makna. Dari uraian di atas dapat diartikan bahwa menulis tidak sekedar menggambarkan simbol-simbol grafis, tetapi di dalamnya mengandung gagasan, ide, buah pikiran yang runtut. Kemampuan menulis juga menuntut adanya kemampuan mengorganisasikan ide atau gagasan melalui kalimat-kalimat secara tertulis sehingga mudah dipahami.

Kata naskah dalam Kamus Besar Bahasa Indonesia (KBBI), diartikan karangan seseorang sebagai karya asli (KBBI: 2006), sedangkan drama adalah cerita atau kisah yang melibatkan konflik atau emosi, dirancang untuk dipentaskan sebagai pertunjukan teater (KBBI: 2006). Jadi yang dimaksud naskah drama ialah sebuah 
karangan yang berisi kisah perjalanan hidup manusia yang sarat dengan konflik yang akan dipentaskan di atas panggung.

Pembelajaran kooperatif adalah pembelajaran dengan sistem pembentukan kelompok dalam proses kegiatannya. Kelompok terdiri dari 4-5 orang. Keuntungan pembelajaran kooperatif adalah: 1) meningkatnya hasil belajar pada siswa, 2) terpupuknya kerja sama dalam diri siswa 3) toleransi antar siswa semakin baik, 4) kepercayaan diri siswa meningkat, 5) siswa menjadi lebih bersemangat untuk belajar, berpikir, memecahkan masalah, dan menerapkan ilmu pengetahuan serta keahliannya (Sudarsana, 2018:3). Dengan menerapkan model pembelajaran kooperatif siswa tidak bekerja secara individu, tetapi bekerja secara bersamasama, berinteraksi secara terbuka yang bersifat interdependensi efektif dalam kelompoknya. (Rustaman, dkk. 2003: 206).

"Dapil Tebu Itam" merupakan akronim atau singkatan dari: (1) Daftar peristiwa. Maksudnya siswa mendaftar peristiwa-peristiwa menarik yang pernah dialami selama hidupnya. Mengingat pada saat menulis naskah drama siswa kesulitan menemukan ide cerita sebagai inspirasi yang akan dituliskan kedalam sebuah naskah drama. Jadi melalui peristiwa yang pernah dialaminya sendiri siswa terbantu untuk menemukan ide cerita. (2) Pilih satu peristiwa. Maksudnya dari daftar peristiwa yang sudah ditentukan, maka perlu dipilih satu peristiwa saja berdasarkan kesepakatan kelompoknya. Kegiatan lebih tepat dilakukan secara kelompok mengingat kegiatan ini memerlukan pemikiran dan waktu yang cukup lama. Peristiwa inilah yang akan diangkat sebagai tema cerita. (3) Tentukan tema. Sebuah naskah drama hendaknya berpusat pada tema, karena tema merupakan dasar cerita yang akan dikembangkan menjadi sebuah cerita. (4) Buat alur. Maksudnya peristiwa- peristiwa yang dialami tokoh diurutkan sehingga akan kelihatan rangkaian peristiwanya atau alurnya. Ada alur maju, alur mundur, atau alur gabungan. Dari sini juga akan kelihatan konfliknya. Perlu diketahui bahwa letak kemenarikan sebuah drama adalah adanya konflik. Untuk itu keberadaan konflik sangat penting. Tanpa konflik drama itu bagaikan sayur tanpa garam, hambar dan tidak menarik. (5) Identifikasi latarnya. Latar meliputi waktu, tempat, dan suasana yang melingkungi cerita. (6) Tentukan tokoh. Dalam sebuah drama tentu ada tokoh atau pelaku yang melakonkan cerita. Ada tokoh protagonis (bersifatbaik, disukai penonton), tokoh antagonis (bersifat tidak baik atau jahat), dan tokoh tritagonis (tokoh penengah), dan (7) Amanat, adalah pesan yang akan disampaikan kepada penonton. Sebuah karya sastra drama yang baik mengandunga jaran-ajaran tentang kehidupan yang dituangkan melalui pesan atau amanat. Akronim itu mudah diingat, dan itu merupakan langkah atau urutan atau tahapan yang harus dilakukan siswa dalam membuat naskah drama. Sehingga sampai kapan pun siswa akan ingat akronim itu yang secara otomatis akan membantu mereka dalam membuat naskah drama pada masa yang akan datang.

\section{Metode Penelitian}

Penelitian ini menggunakan jenis Penelitian Tindakan Kelas (PTK) yang dilaksanakan secara kolaboratif dan partisipatif. Peneliti tidak melakukan penelitian secara mandiri, tetapi berkolaborasi atau bekerja sama dengan teman guru sesama guru Bahasa Indonesia. Penelitian ini menekankan pada peningkatan kemampuan menulis naskah drama. Penelitian ini menggunakan pendekatan deskriptif kualitatif.

Subjek penelitian adalah siswa kelas XI IPS1 SMAN 1 Banguntapan, berjumlah 32 siswa, sedangkan objek penelitiannya adalah menulis naskah drama.

Penelitian dilakukan di SMA Negeri 1 Banguntapan yang beralamat di Ngentak, Baturetno, Banguntapan, Bantul, Yogyakarta, telepon (0274) 373824Penelitian dilakukan pada bulan Januari sampai bulan Februari tahun pelajaran 2019/2020. Dilaksanakan dalam dua siklus, dengan jumlah pertemuan setiap siklusnya adalah dua kali tatapmuka.

Penelitian tindakan kelas ini menggunakan model spiral dari Kemmis dan Targart secara skematis model Kemmis dan Targart dijelaskan pada gambar 1 berikut.

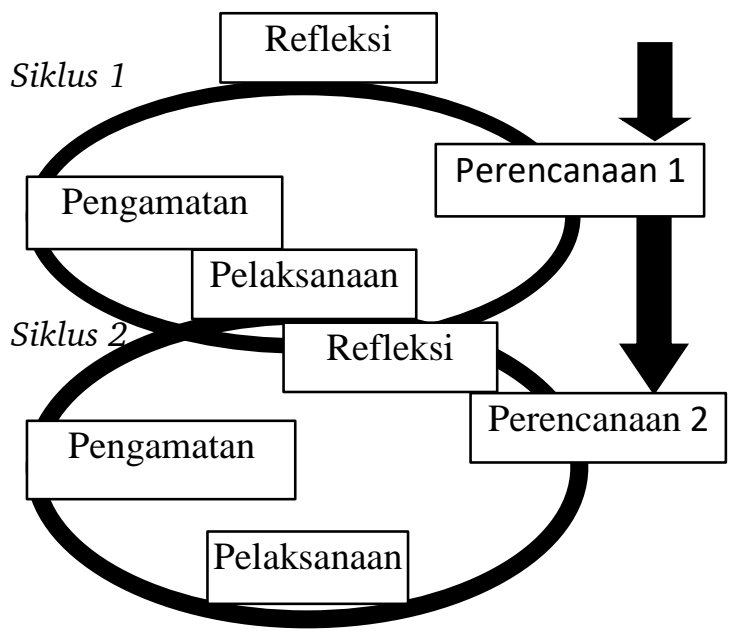

Gambar 1. Proses Penelitian Tindakan Kelas model spiral dari Kemmis dan Targart 
Tindakan dalam penelitian ini dilakukan dalam dua siklus. Tiap-tiap siklus terdiri dari empat tahapan tindakan. Empat tahapan tersebut adalah perencanaan (planning), pelaksanaan tindakan (acting), pengamatan (observing), dan refleksi (reflecting). Empat tahapan itu dilakukan dalam satu spiral yang saling terkait. Sebelumnya diawali dengan penilaian pretest tentang kemampuan menulis naskah drama.

\section{Siklus I}

Pada tahap perencanaan (planning), guru membuat Rencana Pelaksanaan Pembelajaran (RPP), menyusun instrumen lembar kerja (LK) berbentuk daftar checklist tentang keterlaksanaan langkah-langkah penulisan naskah drama dengan urutan Dapil Tebu Itam, menyusun lembar observasi (LO)siswa dan guru berupa checklist berisi keaktifan selama proses pembelajaran, menyiapkan media penggalan drama pendek "Anak", oleh Teater Alam Banda Aceh, karya Putu Wijaya, untuk pertemuan pertama dan Drama berjudul Bening" karya Serafin dan Joaquin Alvares, untuk pertemuan kedua, menyiapkan alat LCD.

Pada tahap pelaksanaan tindakan (acting), siswa menyaksikan tayangan drama pendek, siswa menyebutkan unsur-unsur pembangun drama yang meliputi tema, alur, tokoh, latar dan amanat. Setelah itu siswa dibentuk kelompok terdiri dari 4-5 orang; siswa menerima lembar kerja (LK) berupa tabelberisi langkah-langkah penulisan naskah drama dengan sistematika Dapil Tebu Itam seperti pada tabel 1. Pertama, siswa mendaftar peristiwa-peristiwa menarik yang pernah dialami selama hidupnya. Kedua, siswa menentukan satu peristiwa berdasarkan kesepakatan kelompoknya. Ketiga, siswa menentukan tema apa yang akan diangkat dalam cerita dalam naskah dramanya. Keempat, siswa menentukan alur atau rangkaian peristiwanya. Kelima, siswa menentukan penokohan dalam cerita. Keenam, siswa menentukan amanat atau pesan apa yang akan disampaikan kepada penonton. Selanjutnya siswa melaporkan hasil pekerjaannya untuk ditanggapi temannya. Guru memberikan penguatan.

Pada tahap pengamatan (observing), peneliti dalam hal ini adalah guru bersama dengan teman sejawat sebagai kolaboran mengamati atau mengobservasi seluruh proses kegiatan pembelajaran dengan mengisi lembar observasi siswa. Selain itu pengamatan juga ditujukan pada ketepatan hasil kerja siswa dalam mengisi lembar kerja. Kolaboran mengamati kegiatan guru selama proses pembelajaran dengan mengisi lembar observasi guru.
Pada tahap refleksi (reflecting), hasil analisis kegiatan pembelajaran siklus I adalah sebagai berikut: Dari data nilai diperoleh informasi nilai terendah 70,00 dan nilai tertinggi 80,00. Nilai ini sudah mengalami peningkatan dibandingkan dengan nilai pretest. Berdasarkan lembar kerja (LK)) siswa masih mengalami kesulitan pada saat menentukan alur dan menentukan penokohan, sehingga pada kedua unsur itu siswa masih memperoleh skor yang rendah. Dari lembar observasi didapatkan data siswa mengikuti dengan cukup baik meskipun belum menunjukkan motivasi yang tinggi. Hal ini disebabkan oleh kekurangpahaman siswa terhadap materi sehingga siswa agak kesulitan mengisi lembar kerja. Berdasarkan kekurangan di atas guru bersama kolaboran menyusun sebuah rancangan perbaikan untuk dilaksanakan pada pembelajaran siklus II. Rancangan perbaikannya adalah: pada kegiatan awal guru menjelaskan manfaat menulis naskah drama dari segi kreativitas dan finansial untuk menumbuhkan motivasi siswa; pada kegiatan inti, media drama diganti dengan judul yang lain yang lebih ringan agar siswa lebih dapat memahami isinya; pada saat siswa bekerja dalam kelompok, guru berkeliling membimbing dan mengarahkan berkaitan pengisian lembar kerja.Agar siswa lebih aktif, lembar kerja kelompok yang satu ditukarkan dengan lembar kerja kelompok lain. Beberapa kekurangan di atas membuat guru dan kolaboran bersepakat bahwa kegiatan dengan menggunakan model pembelajaran Kooperatif Dapil Tebu Itam dilanjutkan pada siklus II.

\section{Siklus II}

Pada tahap perencanaan (planning), guru menyusun RPP, menyiapkan instrumen dan rubrik penilaian, menyiapkan lembar observasi keaktifan siswa.

Pada tahap pelaksanaan tindakan (acting), siswa dibentuk dalam kelompok yang sama seperti pada siklus I; tiap kelompok saling menukarkan naskah drama; siswa memberikan tanggapan berkaitan dengan unsur drama sesuai sistematika Dapil Tebu Itam, yang meliputi bagaimana pemilihan peristiwanya, temanya, alurnnya, latarnya, penokohannya, dan amanatnya, apakah semua unsur sudah ada dan sesuai. Guru memberikan penguatan; siswa dipersilakan untuk mengajukan pertanyaan; guru memberikan kesempatan untuk memperbaiki naskah drama sesuai dengan masukan dari temannya dan dari guru; siswa membacakannya di depan kelas; guru memberikan penguatan. Guru memberikan tugas untuk menyempurnakan 
naskah drama dan dijilid untuk dibawa pada pertemuan yang akan datang.

Pada tahap pengamatan (observing), guru sebagai peneliti bersama dengan teman sejawat sebagai kolaboran melakukan pengamatan terhadap proses kegiatan pembelajaran dengan mengisi lembar observasi siswa. Selain itu pengamatan juga ditujukan pada kesesuaian naskah drama dengan instrumen penilaian yang berisi sistematika Dapil Tebu Itam. Kolaboran mengamati kegiatan guru selama proses pembelajaran dengan mengisi lembar observasi guru.

Pada tahap refleksi (reflecting), dari data pengamatan siswa menunjukkan sikap kesiapan, antusias, motivasi, dan keaktifan siswa dalam kategori sangat baik dan ketuntasan kelas juga meningkat, nilai terendah 80,00 dan tertinggi 90,00 . Semua siswa memperoleh nilai dengan kategori tuntas. Dengan demikian maka pengulangan pembelajaran tidak diperlukan lagi.

Data pada penelitian ini diambil berdasarkan hasil observasi dan hasil penilaian berupa tes kemampuan menulis naskah drama. Observasi dilakukan dengan mengamati kinerja siswa dalam melaksanakan tugas dalam kelompoknya.

Penelitian ini menggunakan dua instrumen yaitu: 1) instrumen observasi (pengamatan). Instrumen ini berisi pengamatan terhadap kegiatan siswa dan guru selama proses pembelajaran berlangsung. 2) instrument pengukuran kemampuan menulis naskah drama. Instrumen ini berisi unsur pembangun drama, yaitu tema, alur-konflik, penokohan, setting atau latar, dan amanat.

Teknik pengumpulan data yang digunakan dalam penelitian ini adalah dengan teknik: 1) Observasi atau pengamatan. Dengan menggunakan lembar observasi, guru dan kolaboran merekam secara tertulis seluruh perilaku atau sikap siswa dan guru selama kegiatan belajar mengajar secara lengkap. Perilaku atau sikap yang dicatat meliputi: Observasi keaktifan siswa saat menggunakan model kooperatif "Dapil Tebu Itam" di dalam kelas dan observasi pelaksanaan kegiatan pembelajaran yang dirancang guru. 2) Tes kemampuan tertulis tiap siklus digunakan untuk menilai penguasaan materi menulis naskah drama pada siswa, setelah siswa mengikuti pembelajaran model kooperatif "Dapil Tebu Itam" yang telah dirancang guru, sehingga kemampuan siswa dalam menguasai materi menulis naskah drama tergambar dengan jelas dan hasil belajarnya akurat.
Setelah data terkumpul kemudian dianalisis secara deskriptif kualitatif. Secara deskriptif yaitu data disajikan dalam bentuk uraian dan pembahasan yang berdasarkan hasil penelitian. Teknik kualitatif digunakan untuk mengetahui keterlaksanaan penelitian tindakan kelas dan merumuskan hambatan-hambatan yang muncul dalam upaya meningkatkan kemampuan siswa menulis naskah drama dengan menggunakan model pembelajaran Kooperatif "Dapil Tebu Itam". Deskripsi aktivitas belajar siswa didasarkan pada hasil observasi dengan menggunakan lembar observasi. Lembar observasi mencatat hasil observasi sikap atau perilaku guru dan siswa dengan lengkap meliputi: Observasi keaktifan siswa saat menggunakan model kooperatif "Dapil Tebu Itam" di dalam kelas dan observasi pelaksanaan kegiatan pembelajaran yang dirancang guru. Analisis data bertujuan untuk mengetahui kemampuan menulis naskah drama pada siswa, dilihat dari nilai ketuntasan belajar yaitu:

ketuntasan individual dengan rumus:

$\mathrm{X}=\frac{a}{b} \times 100 \%$

Keterangan :

$\mathrm{X}=$ Persentase ketuntasan belajar individu

$a$ = Jumlah skor yang diperoleh siswa

$b=$ Jumlah skor maksimal

ketuntasan klasikal dengan rumus:

$\mathrm{Y}=\frac{p}{q} \times 100 \%$

Keterangan :

$\mathrm{Y}=$ Persentase ketuntasan klasikal

$p=$ Jumlah siswa yang mendapat nilai $\geq 76$

$q=$ Jumlah seluruh siswa

Penelitian tindakan kelas ini dikatakan berhasil jika: 1) Siswa dapat menulis naskah drama dengan memenuhi unsur- unsur pembangun drama berikut: tema, alur-konflik, penokohan, seting atau latar, dan amanat. Nilai ketuntasan yang ditargetkan 100\% dengan nilai KKM minimal 76,00 ; 2) Kemampuan menulis drama siswa mengalami peningkatan, dibuktikan dengan perolehan nilai rerata kelas 85,00.

\section{Hasil dan Pembahasan}

Keberhasilan kegiatan belajar mengajar sangat dipengaruhi oleh kemampuan guru dalam melaksanakan seluruh proses pembelajarannya. Model pembelajaran yang dipilih guru juga besar pengaruhnya dalam meningkatkan hasil belajar siswa. Pemilihan model pembelajaran kooperatif dimaksudkan untuk meningkatkan hasil belajar 
atau kemampuan siswa. Selain itu juga untuk memupuk jiwa sosial dengan menghormati sesama teman, melaksanakan aturan dalam kelompoknya, bertanggung jawab atas tugas individunya, dan menumbuhkan rasa toleransi. Dengan berkelompok siswa menjadi lebih aktif dalam mengikuti pembelajaran sehingga dampaknya adalah hasil belajar atau kemampuan siswa meningkat (Irwan N dan Sani RA, 2015).

Sebelum dilakukan tindakan, peneliti mengadakan pretest. Hasilnya dari 32 siswa, hanya 16 siswa yang memperoleh nilai dengan keterangan tuntas. Sedangkan 16 siswa lainnya belum tuntas. Perolehan hasil nilai pretestseperti tertera dalam tabel 1.

Tabel 1. Hasil nila ipretest kemampuan menulis naskah drama

\begin{tabular}{lc}
\hline \multicolumn{1}{c}{ Keterangan } & Hasil \\
\hline Tuntas & 16 siswa $(50 \%)$ \\
Belum tuntas & 16 siswa $(50 \%)$ \\
Nilai tertinggi & 80 \\
Nilai terendah & 50 \\
Rerata & 70 \\
\hline
\end{tabular}

Dari tabel 1 dapat diketahui bahwa diperoleh nilai skor rerata kelas 70,00 dari skor maksimal 100. Ini membuktikan bahwa secara klasikal belum mencapai KKM 76,00. Berdasarkan data itulah, peneliti berusaha mengembangkan pembelajaran dengan menggunakan model Kooperatif Dapil Tebu Itam dengan tujuan meningkatkan kemampuan menulis naskah drama pada siswa kelas XI IPS1.

\section{Siklus I}

Pada pertemuan pertama siswa mengisi tabel yang berisi langkah-langkah menulis naskah drama sesuai dengan sistematika Dapil Tebu Itam seperti pada tabel 2 .

Tabel 2. Lembar Kerja (LK) menulis naskah drama dengan sistematika Dapil Tebu Itam

\begin{tabular}{lll}
\hline No. & \multicolumn{1}{c}{ Langkah } & $\begin{array}{c}\text { Pernya- } \\
\text { taan }\end{array}$ \\
\hline 1 & Daftarlah pengalaman yang & \\
& pernah kalian alami & \\
2 & Pilihlah satu pengalaman yang & \\
& paling menarik \\
3 & Tentukan tema cerita \\
4 & Buatlah jalan ceritanya (alur) \\
5 & Identifikasi latarnya \\
6 & Tentukan tokoh-tokohnya \\
7 & Tentukan amanat yang akan \\
& disampaikan \\
\hline
\end{tabular}

Langkah-langkah kegiatan siswa adalah mengisi kolom pernyataan dengan 1) tiap siswa mendaftarkan pengalaman yang paling menarik yang pernah dialami, 2) dari pengalamanpengalaman yang sudah terdaftar siswa memilih satu pengalaman berdasarkan kesepakatan kelompok, 3) siswa menentukan tema apa yang akan diangkat ke dalam naskah drama, 4) siswa merancang jalan cerita atau alur cerita dalam naskah drama, 5) siswa menentukan latar atau setting cerita yang meliputi tempat dan waktu terjadinya peristiwa dalam cerita, 6) siswa menentukan tokoh-tokoh dalam cerita, baik tokoh utama maupun tokoh pembantu, 7) siswa menentukan amanat atau pesan apa yang akan disampaikan kepada penonton melalui naskah drama yang dibuat; siswa melaporkan hasil pekerjaannya, siswa yang lain menanggapi. Guru memberikan penguatan.

Pada kegiatan penutup diakhiri dengan pemberian tugas, siswa diberi tugas untuk melengkapi lembar kerja sesuai dengan masukan dari temannya dan dari guru. Hasil penilaian siklus I terdapat dalam tabel 3.

Tabel 3. Hasil Nilai Menulis Naskah Drama Siklus Pertama

\begin{tabular}{lc}
\hline Keterangan & Hasil \\
\hline Tuntas & 20 siswa $(62,5 \%))$ \\
Belum tuntas & 12 siswa $(37,5 \%)$ \\
Nilai tertinggi & 80 \\
Nilai terendah & 70 \\
Rerata & 75 \\
\hline
\end{tabular}

Tabel 3 memberikan informasi bahwa baru 20 siswa yang memperoleh nilai dengan keterangan tuntas, sedangkan 12 siswa belum tuntas. Nilai tertinggi 80,00 dan nilai terendah 70,00 dengan nilai rerata 75,00. Meskipun data ini menunjukkan sudah ada peningkatan, tetapi belum seperti yang diinginkan yaitu mencapai nilai rerata 85,00 dengan ketuntasan $100 \%$. Dari lembar observasi siswa diketahui bahwa siswa masih belum semuanya aktif, antusias dan termotivasi mengikuti pembelajaran. Dari hasil refleksi dengan kolaboran, disepakati pembelajaran harus diulang pada siklus II dengan sedikt perubahan kegiatan untuk mengatasi masalah yang terjadi pada siklus I. Adapun perubahannya adalah pada kegiatan inti dilakukan saling menukar naskah drama antarkelompokuntuk diberi tanggapan atau masukan oleh temannya. Hal ini dilakukan dengan tujuan agar siswa lebih aktif, antusias, dan termotivasi mengikuti pembelajaran. 


\section{Siklus kedua}

Data nilai siklus kedua menunjukkan adanya peningkatan nilai yang signifikan. Dari 32 siswa, semua mendapatkan nilai di atas KKM 76,00. Data Nilai Menulis Naskah Drama Siklus Kedua dapat dilihat di tabel 4.

Tabel 4. Hasil Nilai Menulis Naskah Drama Siklus Kedua

\begin{tabular}{lc}
\hline \multicolumn{1}{c}{ Keterangan } & Hasil \\
\hline tuntas & 32 siswa $(100 \%)$ \\
\hline Belum tuntas & 0 siswa $(0 \%)$ \\
\hline Nilai tertinggi & 90 \\
\hline Nilai terendah & 80 \\
\hline rerata & 85 \\
\hline
\end{tabular}

Data tersebut menunjukkan bahwa dari 32 siswa, semua memperoleh nilai dengan kategori tuntas. Nilai tertinggi 90,00 dan nilai terendah 80,00 . Nilai rerata kelas 85,00 . Berdasarkan data di atasmaka pembelajaran menulis naskah drama tidak perlu diulang.

Peningkatan nilai rerata kelas dari pretest, siklus 1, dan siklus 2, dapat dilihat pada diagram1. Peningkatan persentase ketuntasan hasil belajar seperti terdapat pada gambar 2 .

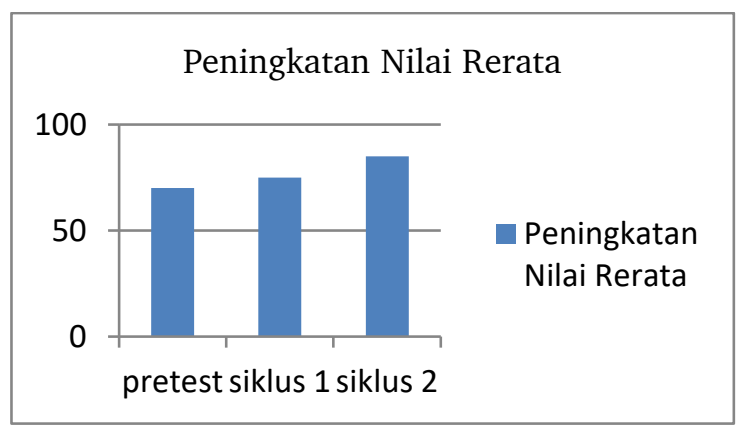

Gambar 2. Grafik Peningkatan Nilai Rerata Kelas

Dari diagram1 dapat dilihat dengan jelas peningkatan rerata kelas pada saat pretest 70,00 , siklus 1 meningkat menjadi 75,00 , dan pada siklus 2 meningkat menjadi 85,00.

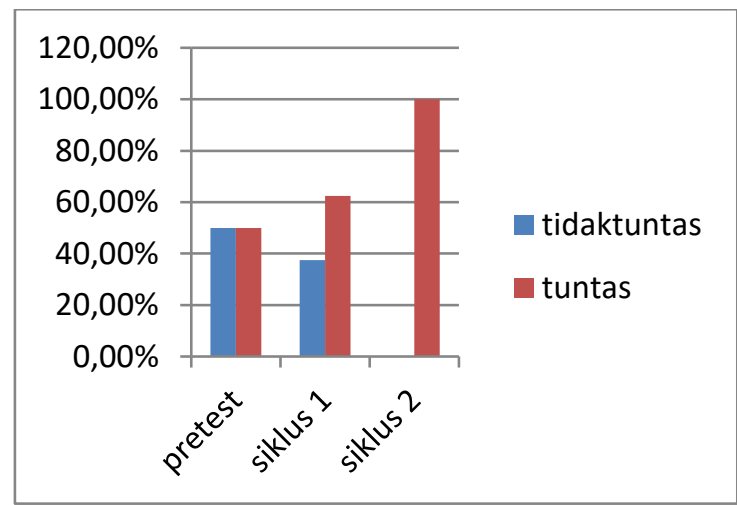

Gambar 3. Grafik Peningkatan Persentase Ketuntasan Hasil Belajar
Persentase peningkatan ketuntasan belajar hasil belajar siswa dapat dilihat pada gambar 3 . Gambar 3 dapat menjelaskan adanya peningkatan persentase ketuntasan hasil belajar siswa. Kegiatan pretest tingkat ketuntasanntnya $50 \%$, meningkat menjadi $60 \%$ pada siklus 1 dan meningkat lagi menjadi $100 \%$ pada siklus 2 .

Peningkatan kemampuan menulis naskah drama pada siswa dengan menerapkan model pembelajaran Kooperatif Dapil Tebu Itam dari pretest, siklus I dan siklus II ini juga berdampak pada aktivitas belajar siswa. Hasil observasi siswa dapat dilihat pada tabel 5 .

Tabel 5. Hasil Observasi siswa

\begin{tabular}{|c|c|c|c|c|c|c|}
\hline \multirow{2}{*}{ Indikator } & \multicolumn{2}{|c|}{$\begin{array}{l}\text { Sebelum } \\
\text { tindakan }\end{array}$} & \multicolumn{2}{|c|}{ Siklus I } & \multicolumn{2}{|c|}{ Siklus II } \\
\hline & $\%$ & $\begin{array}{c}\text { Kate- } \\
\text { gori }\end{array}$ & $\%$ & $\begin{array}{l}\text { Kate- } \\
\text { gori }\end{array}$ & $\%$ & $\begin{array}{c}\text { Kate- } \\
\text { gori }\end{array}$ \\
\hline Kesiapan & 70 & baik & 80 & baik & 90 & $\begin{array}{c}\text { sangat } \\
\text { baik }\end{array}$ \\
\hline Motivasi & 70 & baik & 75 & baik & 90 & $\begin{array}{c}\text { sangat } \\
\text { baik }\end{array}$ \\
\hline Antusias & 60 & cukup & 80 & baik & 90 & $\begin{array}{c}\text { sangat } \\
\text { baik }\end{array}$ \\
\hline Keaktifan & 70 & baik & 85 & baik & 90 & $\begin{array}{c}\text { sangat } \\
\text { baik }\end{array}$ \\
\hline Rerata & 68 & baik & 80 & baik & 90 & $\begin{array}{c}\text { sangat } \\
\text { baik }\end{array}$ \\
\hline
\end{tabular}

Tabel 5 di atas memberikan informasi adanya peningkatan sikap siswa selama pembelajaran. Sebelum tindakan, keaktifan siswa hanya 68\%, meningkat pada siklus I menjadi $80 \%$, dan meningkat lagi pada siklus II menjadi 90\%. Berdasarkan data di atas dapat diperoleh fakta bahwa dengan adanya peningkatan sikap siswa perhadap proses pembelajaran, hasil belajar khususnya kemampuan menulis naskah drama pada siswa meningkat.

\section{Simpulan dan Saran}

Penelitian ini menyimpulkan bahwa model pembelajaran Kooperatif Dapil Tebu Itam dapat meningkatkan kemampuan menulis siswa kelas XI IPS 1 SMA Negeri 1 Banguntapan tahun pembelajaran 2019/2020. Peningkatan tersebut ditunjukkan dengan adanya peningkatan rerata kelas pada saat pretest 70,00 dengan ketuntasan $50 \%$ meningkat pada siklus I rerata kelas menjadi 75,00 dengan ketuntasan $62,5 \%$ dan meningkat lagi pada siklus II rerata kelas 85,00 dengan ketuntasan $100 \%$.

Saran yang dapat penulis sampaikan kepada teman guru adalah: 1) Kemampuan menulis naskah drama dapat meningkat dengan menggunakan model pembelajaran yang efektif dan bermakna. Untuk itu pilihlah model 
pembelajaran yang mudah dilakukan, bermakna, dan efektif. 2) Gunakan langkah-langkah dalam Model Pembelajaran Kooperatif Dapil Tebu Itam untuk melaksanakan proses pembelajaran dengan materi menulis naskah drama karena sudah terbukti dapat meningkatkan kemampuan menulis naskah drama pada siswa kelas XI IPS 1 SMA Negeri 1 Banguntapan tahun pembelajaran 2019/2020. 3) Penulis berharap Model Pembelajaran Kooperatif Dapil Tebu Itamini menginspirasi para guru agar dapat menciptakan model lain dalam pembelajarannya.

\section{Daftar Pustaka}

Badan Pengembangan dan Pembinaan Bahasa. (2016). Kamus Besar Bahasa Indonesia Edisi Kelima. Jakarta: Balai Pustaka

Depdiknas. (2006). Panduan Pengembangan Silabus Mata Pelajaran Bahasa Indonesia. Jakarta: Dirjen Pendidikan.

Irwan, N dan Sani RA. (2015). Efek Model Pembelajaran Kooperatif Tipe Group Investigation dan Teamwork Skills terhadap Hasil Belajar Fisika. Jurnal Pendidikan Fisika, 4(1).

Kemmis, S. and McTaggart, R. (1988). TheAction Research Reader. Victoria: Deakin University Press.
Peraturan Menteri Pendidikan Nasional Republik Indonesia No. 41 Tahun 2007 tentang Standar Proses untuk Satuan Pendidikan Dasar dan Menengah.

Rustaman, N.Y., dkk. (2003). Strategi Belajar Mengajar Biologi. Bandung: Jurusan Pendidikan Biologi FPMIPA UPI.

Sudarsana, I Ketut. (2018). Pengaruh Model Pembelajaran Kooperatif terhadap Peningkatan Mutu Hasil Belajar Siswa. Jurnal Penjaminan Mutu Lembaga Penjaminan Mutu Institut Hindu Dharma Negeri Denpasar, 4(1).

Tarigan, Henry Guntur. (1993). Menulis Sebagai Suatu Keterampilan Berbahasa. Bandung: Angkasa.

Tim Peneliti Program Pascasarjana UNY. (2001). Pedoman Khusus Pengembangan Sistem Hasil Belajar Berbasis Kemampuan Dasar Siswa SMU Mata Pelajaran Bahasa dan Sastra Indonesia. Yogyakarta: Program Pascasarjana UNY.

Undang-Undang Republik Indonesia No. 20 Tahun 2003 tentang Sistem Pendidikan Nasional. 